
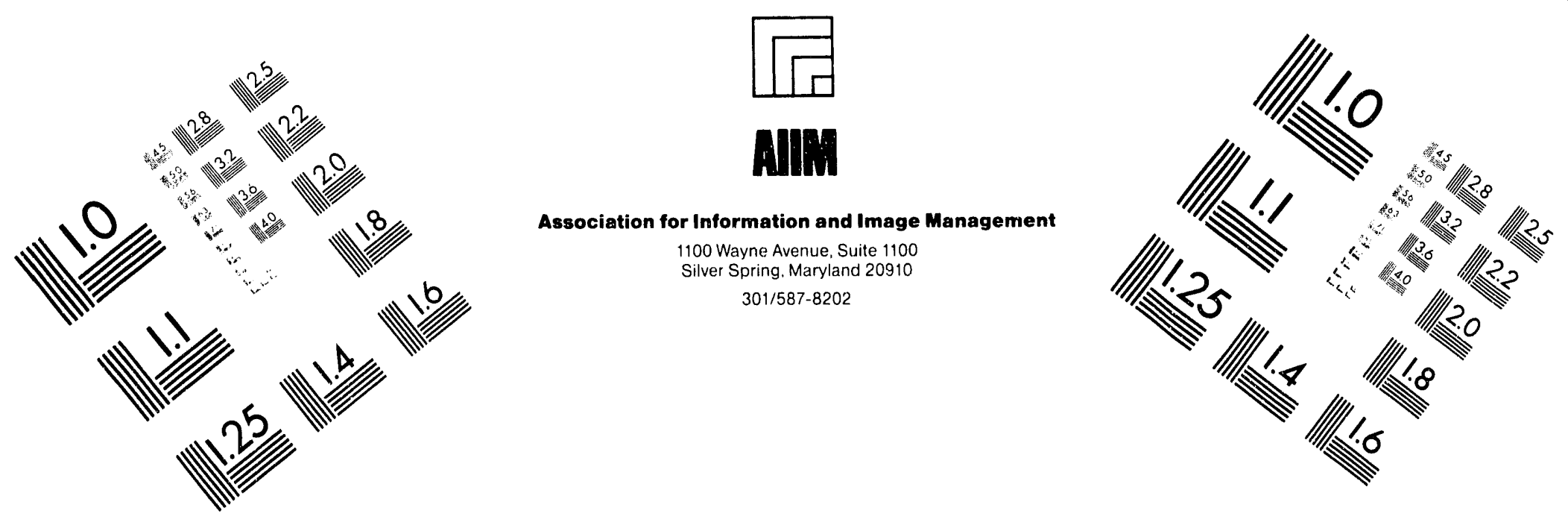

Centimeter

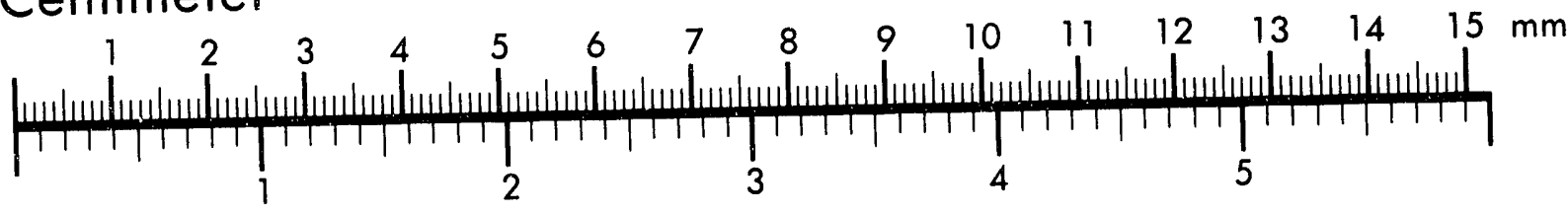
Inches
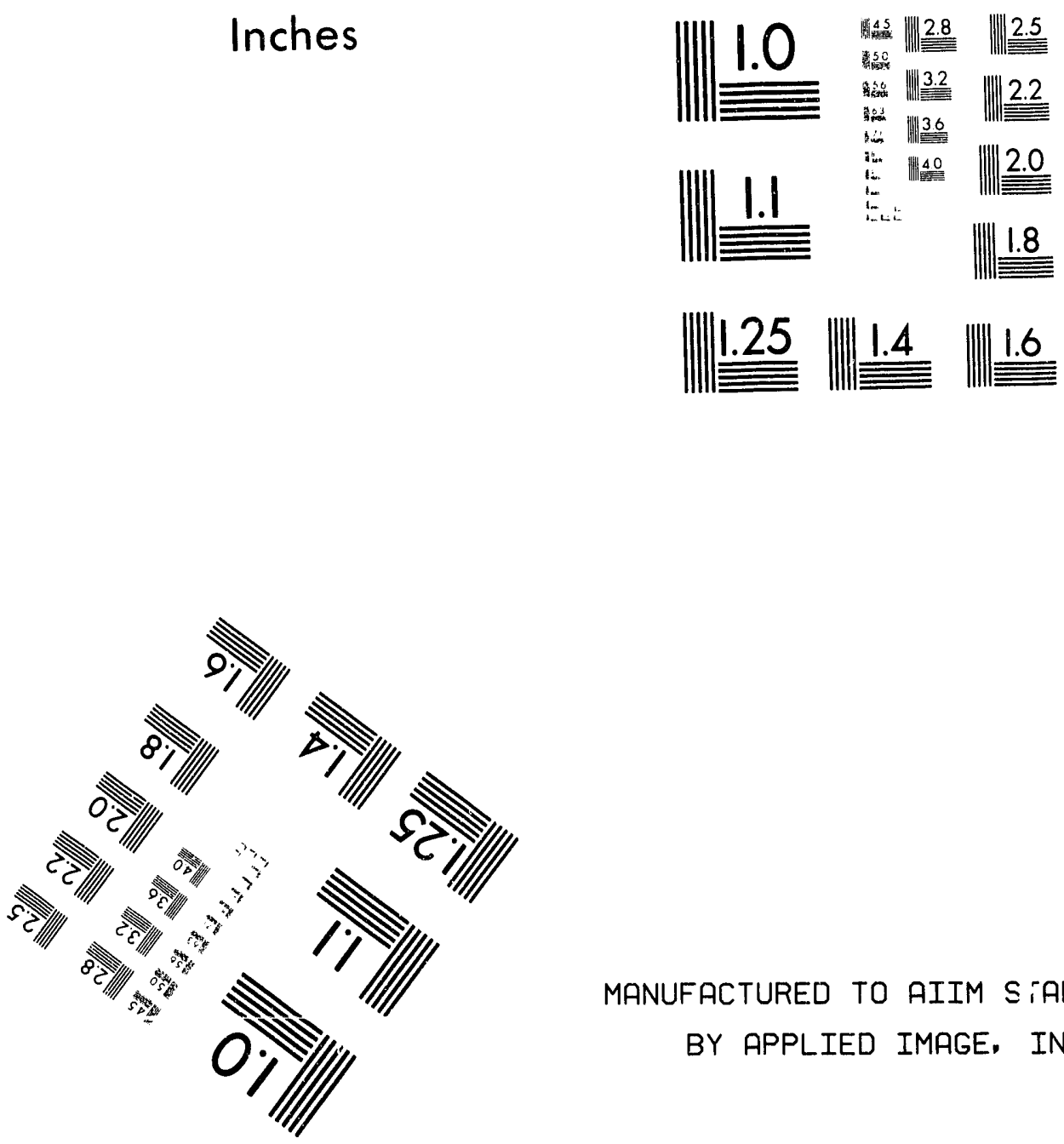

MANUFACTURED TO AIIM SIANDARDS

BY APPLIED IMAGE, INC.

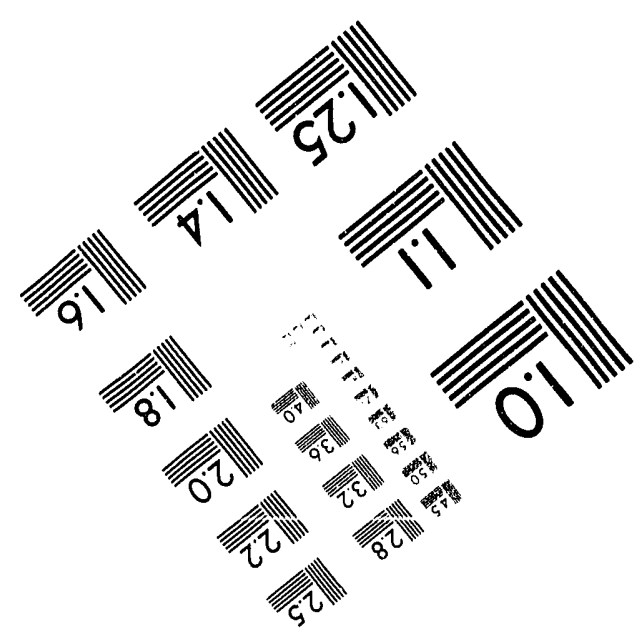



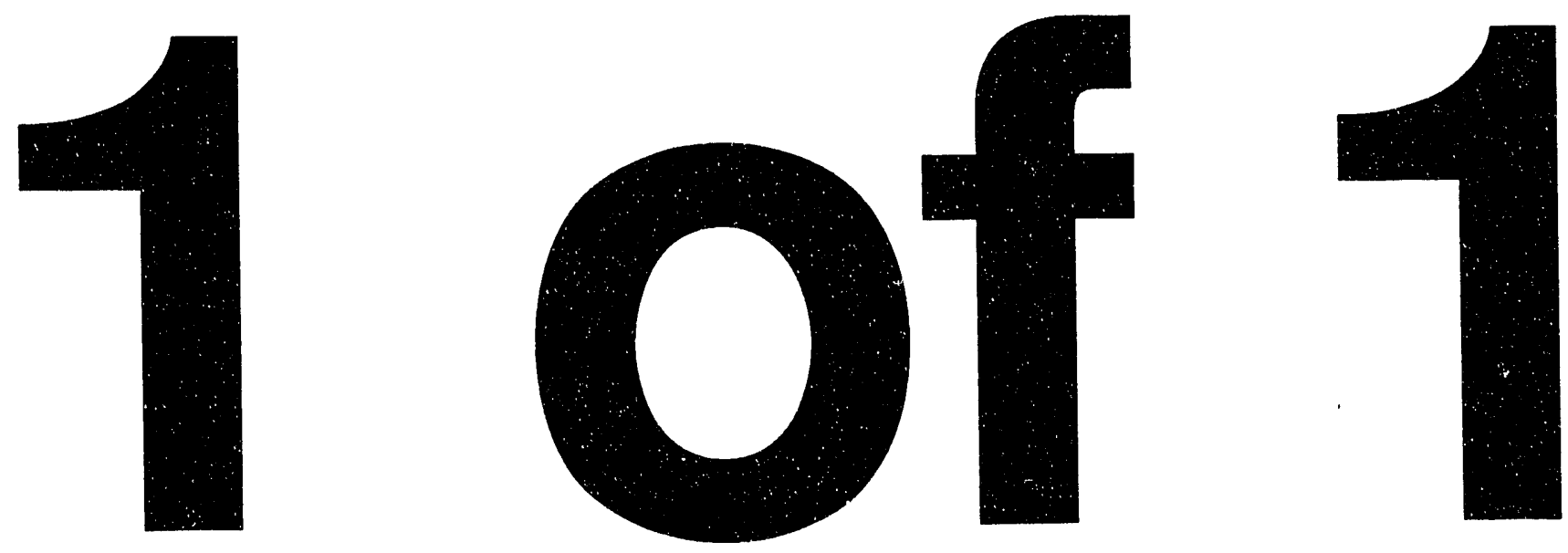


\section{DWPF RECYCLE STREAM CORROSION TESTS (U)}

by

P. E. Zapp

Westinghouse Savannah River Company

Savannah River Site

Aiken, South Carolina 29808

This paper was prepared in connection with work done under the above contract number with the U.S. Department of Energy. By acceptance of this paper, the publisher and/or recipient acknowledges the U. S. Government's right to retain a nonexclusive, royalty-iree license in and to any copyright covering this paper, along with the right to reproduce and to authorize others to reproduce all or part of the copyrighted paper. 


\section{DISCLAIMER}

This report was prepared as an account of work sponsored by an agency of the United States. Government. Neither the United States Government nor any agency thereof, nor any of their employees, makes any warranty, express or implied, or assumes any legal liability or responsibility for the accuracy, completeness, or usefulness of any information, apparatus, product, or process disclosed, or represents that its use would not infringe privately owned rights. Reference herein to any specific commercial product, process, or service by trade name, trademark, manufacturer, or otherwise does not necessarily constitute or imply its endorsement, recommendation, or favoring by the United States Government or any agency thereof. The vicws and opinions of authors expressed herein do not necessarily state or reflect those of the United States Government or any agency thereof.

This report has been reproduced directly from the best available copy.

Available to DOE and DOE contractors from the Office of Scientific and Technical Information, P. O. Box 62, Oak Ridge, TN 37831; prices available from (615) 576-8401.

Available to the public from the National Technical Information Service, U. S. Department of Commerce, 5285 Port Royal Rd., Springfield, VA 22161. 


\section{INTER-OFFICE MEMORANDUM}

April 21, 1993

TO:

G. T. Chandler, 773-A

FROM: P. E. Zapp, 773-A P.t.Z zapp

Approved by:

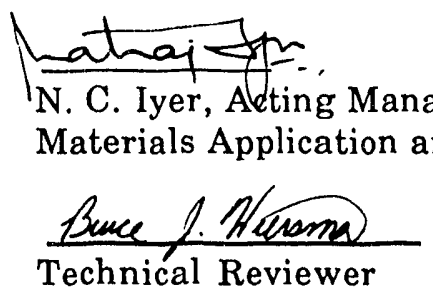
$\frac{\text { D. Thomos Ranhin }}{\text { Autho: ized Derivative Classifier }}$

Materials Application and Corrosion Technology Group

Technical Reviewer

\section{DWPF RECYCLE STREAM CORROSION TESTS (U)}

\section{SUMMARY}

Coupon immersion tests were performed on ASTM A537 Class 1 carbon steel in simulated DWPF recycle solutions at $90 \pm 2^{\circ} \mathrm{C}$, as part of the continuing effort to investigate the formation of shock-sensitive deposits. Coupons were partially immersed for four months in solutions of the same composition used previously at SRTC and at the DuPont Engineering Test Center (a salt solution containing $0.5 \mathrm{M}$ hydroxide and $0.043 \mathrm{M}$ nitrite). Shock-sensitive deposits were not seen on the coupons from this test. There was considerable general corrosion above the water line due to condensate and distilled water contact of the steel. New immersion tests are being planned for completion by September, 1993. The new test solution will reflect the recycle stream chemistry changes brought about by planned ammonia scrubbing in the DWPF.

\section{BACKGROUND}

Contaminated waste water generated in the Defense Waste Processing Facility (DWPF) will be collected in the DWPF recycle collection tank (fabricated from alloy C276), where it will be made alkaline, and then pumped to Tank 43 in H-Area. Tank 43 , a Type III waste tank, serves additionally as the $1 \mathrm{H}$ evaporator feed tank and a fresh canyon waste receipt tank. The alkaline recycle stream, amounting to several million gallons per year, will likely be the major input to tank 43 . Necessary corrosion inhibitors will be added to the recycle collection tank so that the recycle stream will neither be corrosive to Tank 43 nor depend upon inhibitors already in that tank for protection.

Corrosion testing of waste tank steel, ASTM A537 class 1 carbon steel (A537), in 
simulated recycle solutions has been conducted since the mid-1980s, with the objective of establishing minimum concentrations of the hydroxide and nitrite corrosion inhibitors. Coupon immersion tests of susceptibility to general and localized corrosion were conducted by the DuPont Co. at the Engineering Test Center (ETC), Newark DE. 1,2 Electrochemical tests for localized corrosion were conducted at SRS in $1988 .^{3}$ The simulants used in both sets of tests were based conservatively on the recycle stream's originating entirely from DWPF melter off-gas concentrate, the most concentrated among the available sources. The composition of one particular simulant (identified as 'Matrix C' solution) thought to be the best estimate of the offgas concentrate is shown in Table 1 . Tests using this simulant were conducted with varied levels of nitrite and hydroxide (and carbonate/bicarbonate in the electrochemical tests).

In the ETC coupon tests, as-received, 600-grit polished A537 coupons were partially immersed in test solution for periods of one month and four months at temperatures of 70 and $90^{\circ} \mathrm{C}$. It was found that $1.7 \%$ hydroxide ( $1 \mathrm{M}$ hydroxide) combined with $0.2 \%$ nitrite inhibited pitting corrosion at $90^{\circ} \mathrm{C}$. Some slight $(<0.001 \mathrm{in}$.) crevice corrosion was found with these inhibitor concentrations, and the overall general corrosion rate was determined to be approximately 0.0005 in. per year. At $0.85 \%$ hydroxide $(0.5 \mathrm{M})$ and $2000 \mathrm{ppm}$ nitrite crevice corrosion was observed. Slightly less crevice and general corrosion were seen on A537 coupons which had been pre-soaked in caustic or stress-relief heat-treated in air prior to immersion.

In the SRS electrochemical corrosion tests, cyclic potentiodynamic polarization scans were conducted at temperatures up to $80^{\circ} \mathrm{C}$. The hydroxide content in these tests was lowered from the ETC solution concentrations to a steady-state value representative of an aqueous film on the tank wall which is saturated with atmospheric carbon dioxide (which depletes hydroxide in the film faster than it can be replenished from the bulk solution). The results of these tests agreer with the ETC coupon results. Localized attack was absent in solutions with a steady-state $\mathrm{pH}$ of 10.18 (which results from an initial hydroxide concentration of $1.7 \%$ ) and with nitrite concentrations of $0.1 \%$ and $0.2 \%$.

In the course of analyzing the four-month ETC coupon immersion tests, shocksensitive deposits were found at and below the liquid-air interface on the coupons, as well as on Teflon ${ }^{\mathrm{TM}}$ washers and string and type 316 stainless steel hardware attached to the coupons. ${ }^{4}$ Generally more deposits formed on the $90^{\circ} \mathrm{C}$ coupons than on the $70^{\circ} \mathrm{C}$ coupons. The deposits were 50 to $100 \mu \mathrm{m}$ in diameter and were determined to be a mercury-based compound, but to this date they have not been precisely characterized. Nor have the precise conditions under which the deposits form been established. The small quantity of deposits produced on the coupons has made analyses difficult.

The issue of shock-sensitive deposits remains important. Coupon immersion tests were conducted at SRTC in 1992 to verify the ETC test results. ${ }^{5}$ A537 coupons were partially immersed for four months in solutions identical to the ETC solution which 
yielded shock-sensitive deposits. Soft, solid particulate deposits were observed on wetted surfaces of the A537 coupons, but the deposits were smaller (1 - 2 mils across) and less numerous compared with those reported in the ETC tests. These deposits however were not shock sensitive. Liquid mercury drops were also observed.

\section{EXPERIMENTAL PROCEDURE}

The first SRTC coupon immersion tests were conducted by placing test bottles in Blue $\mathrm{M}^{\mathrm{TM}}$ ovens. Rapid evaporation of the test solutions required replenishment with distilled water every 2 days. The present tests used different a heating apparatus in an effort to reduce the need for such frequent replacement of evaporated water. The new arrangement used individual water baths made from specially modified 2-liter round flasks, into which were placed a single 1-liter Teflon ${ }^{\mathrm{TM}}$ test bottle and sufficient water to cover half of the bottle. The bath was placed in a heating mantle. Both the bath and the test bottle were equipped with condensers operated in reflux and cooled with recirculated chilled water. Three test set-ups were run at $90^{\circ} \mathrm{C}$ and one set-up at $80^{\circ} \mathrm{C}$. The bath water required only infrequent replenishment, but the solution in the $90^{\circ} \mathrm{C}$ test bottles (which had a $100 \mathrm{~mL} / \mathrm{min}$. air purge) required 2 to 3 additions of distilled water per week. The bath temperatures were maintained within $2^{\circ} \mathrm{C}$ of the set point, except for two excursions to $100^{\circ} \mathrm{C}$, lasting about 18 hours each, in the $80^{\circ} \mathrm{C}$ bath due to failure of the temperature controller.

The solution composition was identical to that used in the previous SRTC immersion test and the 'C-4' ETC solution composition and is shown in Table 1. As before, the coupons used in this study were fabricated from ASTM A537 class 1 carbon steel and supplied by Metal Samples, Ir.c., Munford, Ala. All specimens were tested with a 600 -grit surface finish. One set of four $\mathrm{A} 537$ specimens tested at $90^{\circ} \mathrm{C}$ was heattreated in air for one hour at $1100^{\circ} \mathrm{F}$ to simulate the stress-relieving heat treatment applied to fabricated waste tanks. The coupons were suspended by Teflon ${ }^{\mathrm{TM}}$ insulated wires so that one half of each coupon was immersed in the test solution and the other half exposed to the vapor above the solution.

At the end of their 4-month exposure the coupons were removed, rinsed in acetone and distilled water, and dried at $60^{\circ} \mathrm{C}$ for about 24 hours. (This was the practice used for some of the ETC test coupons which did have shock-sensitive deposits.) The coupons were microscopically examined for pitting corrosion and for solid deposits. The coupons were then cleaned of much of their corrosion products in Clarke's solution (complexed hydrochloric acid) for further pitting evaluation.

\section{DISCUSSION}

The coupons were generally characterized by the absence of any corrosion below the liquid line and by patches of general corrosion above the liquid line. The patches of general corrosion appeared to originate from exposure of the steel to condensate or to distilled water which had inadvertently splashed onto the coupons during the periodic replacement of evaporated solution. None of the coupons showed shocksensitive deposits or deposits of the kind seen in the previous SRTC coupon immersion test, although liquid mercury drops were seen on one coupon. Corrosion 
products and salt deposits were analyzed by x-ray diffraction. The corrosion products were $\mathrm{Fe}_{3} \mathrm{O}_{4}$ magnetite, $\mathrm{Fe}_{2} \mathrm{O}_{3}$ hematite, and $\alpha \mathrm{FeO}-\mathrm{OH}$ goethite, which are all typical of corroded steel. The salt was sodium carbonate monohydrate.

Nearly all of the coupons were free of distinct pitting corrosion. There were deeper penetrations in the patches of general corrosion described above, but these were characterized by a relatively low aspect ratio (depth divided by diameter) and so not described as pitting. One coupon in cre of the sets exposed at $90^{\circ} \mathrm{C}$ did have an area of pitting about $0.6 \mathrm{in}$. above the liquid level. Several pits were clustered together in this area, with the deepest being 0.003 in. ( 3 mils) deep. This is the first observation of apparent pitting on a coupon exposed to the Table 1 solution. The presence of nearby general corrosion on the same coupon, however, precludes a clear conclusion that the Table 1 solution promotes pitting corrosion in carbon steel. This question will be resolved in the additional testing described below.

\section{FUTURE WORK}

The DWPF plan to scrub equipment to prevent the build-up of ammonia nitrate will alter the composition of the recycle stream. Additional coupon tests in solutions with a composition revised to account for ammonia scrubbing will be performed beginning in April, 1993. They are scheduled for completion in September, 1993. The objectives of these tests will be to study the potential for shock-sensitive deposit formation and to establish of inhibitor levels for the revised recycle composition.

\section{REFERENCES}

1. M. K. Carlson, "Materials of Construction Composite Group Meeting," March 6 and 7, 1989 (U)," OPS-WMQ-89-0057, June 23, 1989.

2. J. J. Kvochak to R. Eibling, "Corrosion Testing - Impact Sensitive Deposits," March 3, 1989.

3. J. D. Fritz, "Inhibitor Requirements for the DWPF Recycle Solution," DPST-88-863, September 22, 1988.

4. J. J. Kvochak to M. K. Carlson, " Corrosion Testing - Tank Farm Recycle Solutions," June 16, 1988.

5. P. E. Zapp, "Corrosion Tests of DWPF Recycle Solution (U)," WSRC-TR-92-376, July 28, 1992. 
$\dot{\mathrm{G}}$. T. Chandler

WSRC-TR-93-233

Page 5 of 6

Table 1

Composition of Aqueous Phase of Coupon Test Solutions (ppm)

\begin{tabular}{cc} 
Ionic Species & Concentration \\
\cline { 2 - 2 } & \\
Sulfate & 250 \\
Fluoride & 50 \\
Chloride & 500 \\
Iodide & 20 \\
Nitrate* & 600 \\
Nitrite & 2000 \\
Mercuric** & 400 \\
Hydroxide & \\
Hyd & $0.5 \mathrm{M}$
\end{tabular}

* Nitrate added as sodium nitrate and mercuric nitrate.

** Mercuric added as the nitrate salt. Recipe concentration is before precipitation as the hydroxide. 


\section{Distribution List}

F. F. Cadek, 719-4A

D. B. Amerine, 704-S

J. P. Ortaldo,704-S

H. H. Elder, 704-S

N. F. Chapman,704-27S

E. J. Freed, 704-27S

D. H. McGraw, 704-27S

J. T. Gee, 704-24S

D. C. Iverson, 704-29S

G. T. Wright, 703-H

T. M. Monahon, 703-H

B. L. Lewis, 703-H

J. E. Marra, 703-H

J. R. Chandler, 703-H

T. C. Hsu, 703-H

J. D. Cohen, 730-A

L. M. Papouchado, 773-A

W. L. Tamosaitis, 773-A

E. F. Duhn, 773-A

D. F. Bickford, 773-A

S. D. Fink, 773-A

L. F. Landon, 704-T

R. A. Jacobs, 704-1 T

D. T. Hobbs, 773-A

J. I. Mickalonis, 773-A

B. J. Wiersma, 773-A

MTS Records, c/o D. Gibson-Epps, 773-A

Records Administration, 773-52A (4) 

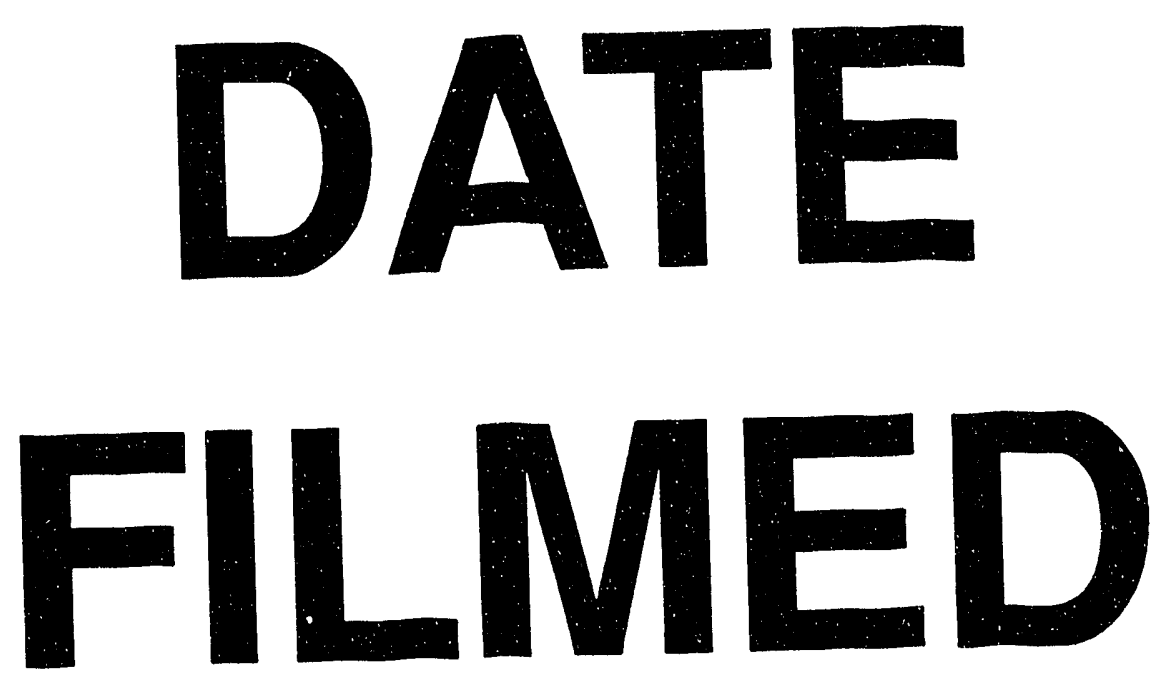

$8 / 4 / 93$
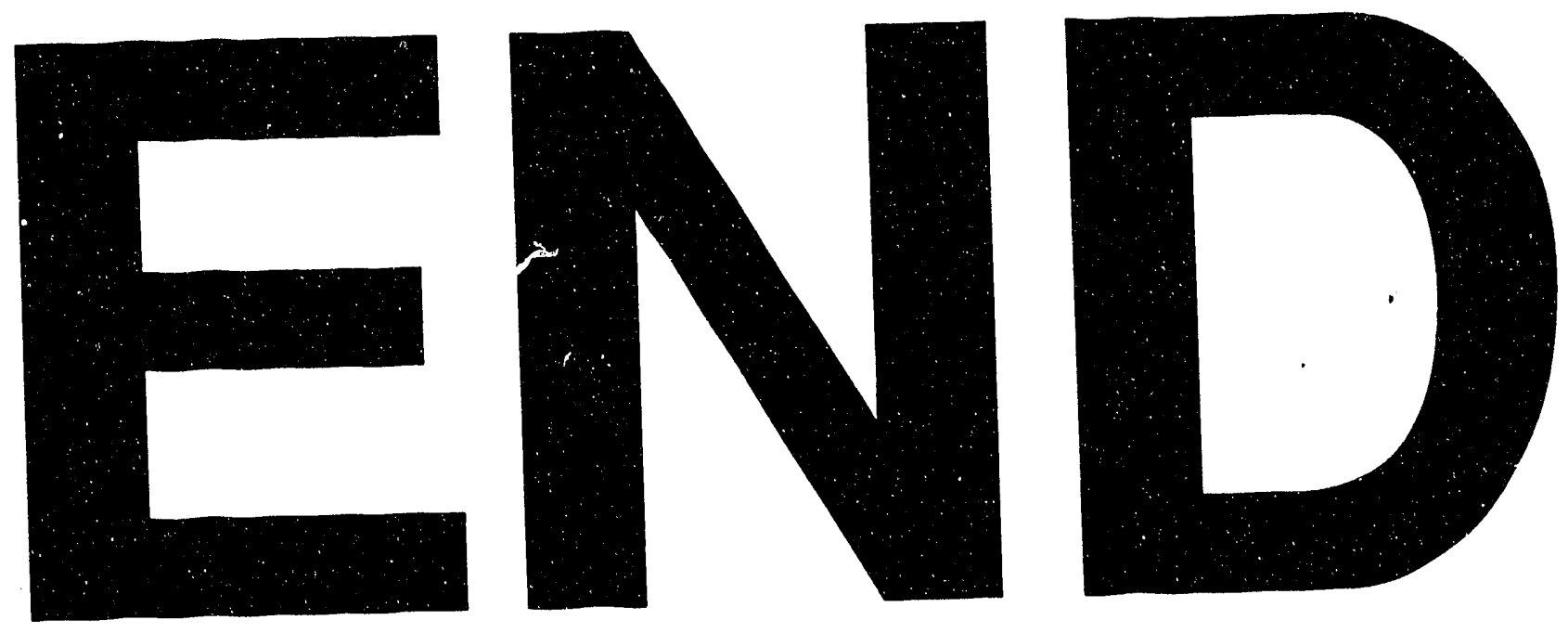
